\title{
The concept of subject-object relations in draft versions of the song "Game" by V.R. Tsoy
}

Svetlana Andreevna Petrova*

*Corresponding author, Pushkin Leningrad State University, 10 Peterburgskoe shosse, Pushkin, 196605, Russia.

DOI 10.12975/rastmd.2021935 Submitted October 11, 2021 Accepted December 27, 2021

\section{Abstract}

The article is devoted to the identification of subject-object relations in the text of the song by V.R. Tsoy. The aim of this work is to analyze the drafts of V.R. Tsoy and characteristics of subject-object relations based on the text of the song "Game" included in the rock album "Night". To achieve this goal, the following methods were used in the work: bibliographic analysis of the literary works and drafts of the writer, the comparative method, the method of analogy and the descriptive method. Based on three versions of the lyrics of the song "Game", the author notes that in the artistic structure of the text, there is a lyrical character that conveys the emotional state, mood and cognitive side of being. The author comes to the conclusion that the key concept of the studied text is "game". This is reflected in the use of the second person plural pronoun "we", as well as in the identification of the author with the lyric hero of the work in question. The scientific novelty of the work lies in the fact that for the first time subject-object relations are analyzed on the material of the song "Game" by V.R. Tsoy.

\section{Keywords}

subject-object relations, V.R. Tsoy, “Game”, rock poetry, rock album.

\section{Introduction}

This research is significant from the perspective of the growing interest in singing poetry, after in 2016 one of the most prominent representatives of this type of poetry - Bob Dylan - was awarded the Nobel Prize in Literature "for creating new poetic expressions in the great American song tradition." The need to study the creativity of Viktor Tsoi is due to appeals to his poetry by subsequent generations of poets, musicians and other representatives of the art of speech. All of the above determined the motivation of the author of this article to consider one of the little-studied aspects of the rock poetry of this author, as well as the choice of the appropriate work.

On the other hand, it should be noted that the choice was also influenced by the general situation presented in the literary process of our time: the installation of postmodernism on the category of play forces us to pay attention to its actualization in texts. An understanding of modernity cannot 
be complete without taking into account the literary facts about it.

\section{Literature review}

In literary criticism the subjectobject relations are revealed through the concepts of subject and object, lyric hero, biographical and artistic image of the author, lyric addressee and lyric character (Murasheva, 2004, p. 13). Authors' drafts can show the development of these relationships and their concepts within the framework of a literary text. Let us consider the above, using the example of the work of V.R. Tsoy and his drafts of the song "Game".

The choice of this particular work is associated with the number of surviving draft fragments of the text of the composition. Information about the drafts is based on the book by Vitaly Kalgin (2016, p. 170-171) "Viktor Tsoy. Life and Cinema".

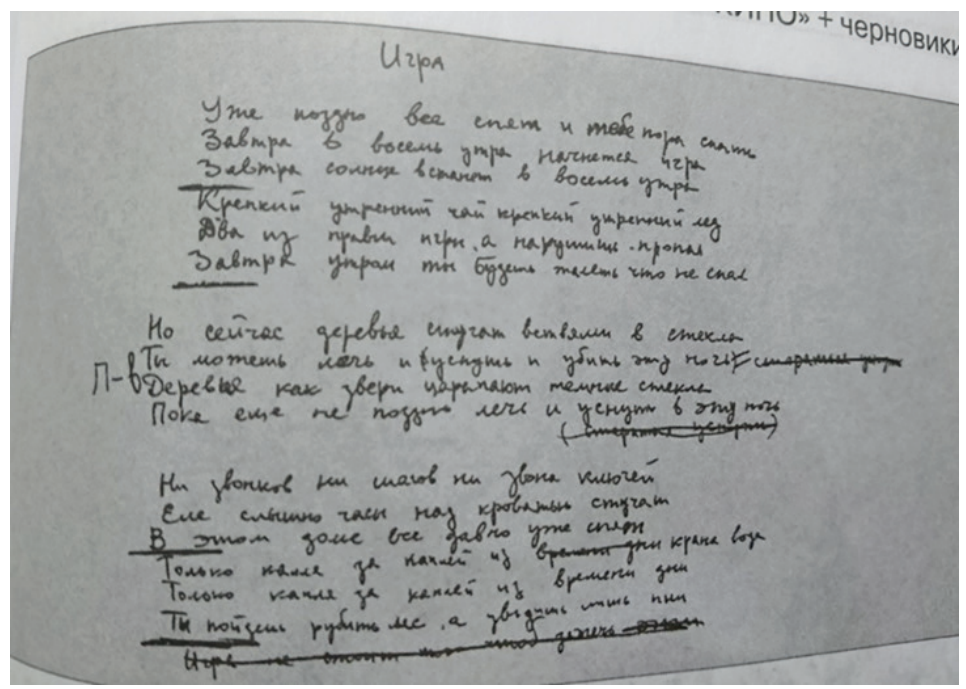

Figure 1. The final version of the song (Kalgin, 2016, p. 170-171)

It should be noted that the song is included in the album "Night" (1986), which includes eleven compositions. According to the theory of rock poetry, a rock album is an artistically organized lyric cycle (Domanskij, 2010). Based on the theory of cyclization, important elements, that form a cycle, are the following: title, composition, isotopy, chronotope and polymetry (Fomenko, 1992). Yu.V. Domansky (2000) writes: or musical direction: limited playing time, obligatory title, visual cover containing a picture and / or photographs, a list of songs and other information about the album (list of participants in the recording, acknowledgements, sometimes lyrics)..." (p. 99).

Thus, it is the genre specificity of the rock album that is emphasized. "the album has certain properties that are characteristic of it, regardless of the time of creation
In rock poetry, the rock album as a genre has all the main features that define the lyric cycle: 
"These are (...) author's contexts; the unity of the compositions included in the album is due to the author's intention; the relationship between individual compositions and an album can be viewed as a relationship between an element and a system; the album is entitled by the author himself (...)" (Domanskij, 2000, p. 100).

Alison Levinge wrote about how the music can enable a client to express her 'true self' (Levinge, 2015), when one makes distinct our connections with the other, subject from object, object from subject. But it is the sphere of psychoanalysis, and couldn't show the problem of poetry. S. Wilson wrote about the value of dialectics in accounting for compositional orientations vis-à-vis their objects - be these objects soundproducing, non-human entities, such as musical instruments, or the object that is 'sound itself' (Wilson, 2020). So, it may be explaining, why the action is very difficult. P. Valiquet considered historical aspects of music themes, but not answer the question about relations of subjects and objects (Valiquet, 2020). A.P. Ashworth wrote abot visual art and music. This is intermedial problem, and also didn't talk about verbal part of the music. (Ashworth, 2021). I.S. PiatnitskaPozdnyakova studied the discursive practice in music, and wrote that it is the subject of special research in philosophical and sociohumanitarian disciplines.

\section{Purpose of the study}

The study of subject-object relations is a significant factor in understanding the concept of a work of art. The purpose of this study is to analyze those categories that show the main specificity of the lyric hero and his position in the picture of the world created by the author in the song "Game", which characterize the subject-object relations in the work.

\section{Methods}

\section{Research Model}

To prepare the work, the following methods were used:

- Bibliographic analysis of the writer's literary works and drafts.

- Comparative method applied when studying drafts of the song "Game".

- The method of analogy when characterizing the main ideas and subject-object relations on the material of the text of the song.

- Descriptive method for introducing necessary concepts.

\section{Data Collection Tools-Documents}

The study is based on biographical research and literary sources, the selection criteria for which were:

- Specificity of the literary text

- Feature of the literary trend

- The individual style of the author

The period of creation of these sources is relevant for creative performances in the 1980-1990s of the twentieth century.

The following types of sources distinguished:

- Biographical

- Artistic 
- Publicistic

Preference was given to those sources that provided reliable and verified information, due to authorship or the authority of the publisher.

\section{Data Analysis}

The first was the bibliographic analysis of the writer's literary works and drafts. Since it was necessary to designate credibility as the basis of the study. Further, the Comparative method applied when studying drafts of the song "Game" and The method of analogy when characterizing the main ideas and subject-object relations on the material of the text of the song were used. Since it was necessary to analyze the specifics of subject-object relations in a literary text.

Then the Descriptive method for introducing necessary concepts was used to summarize.

\section{Process}

The research process was directly related to the study of biographical sources. As the necessary facts appeared, a strategy for further analysis of the text emerged. The phonetic, lexical and syntactic elements of the text were analyzed. Then the patterns of the figurative structure were lined up. The most relevant aesthetic categories associated with the representation of subjectobject relations in the song of V.R. Tsoy "Game".

\section{Results}

\section{Versions of song}

Three versions of the song have survived: among these recordings there are two versions of the first verse and three versions of the second verse with a refrain. In each version of the song there are strikethrough places, as well as changes in the lexical composition.

The first draft of the song "Game" (the strikethrough text in the original draft is indicated in square brackets, the numbering of the author of the article):

1. It's late everyone's asleep and it's time for me to sleep.

2. The windows of the courtyard houses are like a scattering of stars.

3. Tomorrow the sun will rise at 8 in the morning.

4. [Maybe it will be a little warmer and lighter]

5. Maybe the clouds will let the sun shine.

6. Maybe it will be a little warmer than yesterday.

7. Tomorrow the sun will rise at 8 in the morning.

(refrain:)

But now the trees are banging their branches against the windowpane.

You can lie down, fall asleep and kill this night.

Trees like animals scratch the dark windowpane.

[But you] can still [fall asleep and kill] this night

It is still not too late to lie down and fall asleep. (Kalgin, 2016, p. 170).

\section{Analysis of first version}

So in the text of the first verse the following changes are presented:

1. In the first line, the poet uses the case form (dative) of the personal pronoun of the first person singular, which in the final 
text he will replace with the personal pronoun of the second person singular.

2. The line: "The windows of the courtyard houses are like a scattering of stars" will be completely removed, instead of it there will be a phrase: "The game starts tomorrow at eight in the morning" (Tsoy \& Zhitinskij, 1991a, p. 321).

3. The fourth line is completely strikethrough; it is then repeated in a slightly modified form in place of the sixth line. The author removes the possibility of any hope for the best, exacerbates the situation, showing the growing drama of the hero's position.

4. In the final version, the fifth and sixth lines will also be completely transformed in accordance with the changing author's concept.

The poet abandons a number of images in favor of forming the artistic picture of the world he needs. The second person personal pronoun is used in the refrain from the very beginning. It is possible that this influenced the final lyrics of the song.

\section{Specify of final version of the song}

The final version of the first verse is presented as follows:

It's late, everyone's asleep and it's time for you to sleep,

The game starts tomorrow at eight in the morning,

Tomorrow the sun will rise at 8 in the morning.

Strong morning tea, strong morning ice Two of the rules of the game, and if you break them, you are gone,
Tomorrow morning you'll wish you slept. (Tsoy \& Zhitinskij, 1991a, p. 321).

The second draft of the refrain and the beginning of the second verse of the song "Game":

(refrain, numbering of the author of the article)

1. But now the trees are banging their branches against the windowpane

2. You can lie down, fall asleep and kill this night [try to sleep]

3. Trees like animals scratch the dark windowpane

4. It is still not too late to lie down and fall asleep [try to sleep]. (Kalgin, 2016, p. 170).

(second verse, numbering of the author of the article)

1. Only drop by drop [days flow out of time] water flows out of the tap

2. Only drop by drop days flow out of time

3. You will go to cut wood, and you will see only stumps

4. [The game is not worth lighting up the lights]. (Kalgin, 2016, p. 170).

In the text of the refrain, the phrase "try to sleep" is removed. First, it is replaced by "and kill this night", then the line is repeated and the phrase is replaced by "and fall asleep this night". The poet emphasizes the tragedy of what is happening, using a verb "kill" with negative semantics of an aggressive nature. In this context, time is killed, which introduces the semantics of its useless waste. Repetitions create 
syntactic parallelism, as a result of which sleep appears to be a negative action. The demonstrative pronoun ("this") determines the significance of the night period of the day, as well as the overall value of time. The author adds dramatic semantics to the lyrical plot of the song.

\section{Album influence}

The song "Game" ranks tenth in the rock cycle. The name of the cycle emphasizes the importance of a certain category of time, namely of "night". The first, third, fifth and sixth songs of the album emphasize the priority of this time of day for the hero. In the song "Game" this moment is further developed. The day is perceived in this context as filled with nonsense, uselessness of existence. The category of night in this case acquires the semantics of a special time filled with life, the ability to be oneself. But at the same time, the hero runs the risk of breaking the rules of the game of the day in this way. If he does not fall asleep at night, he will not be able to follow the corresponding "rules". Therefore, in the second verse in the draft, the poet removes the fourth line completely: "The game is not worth lighting the lights". In this case, the latter is not associated with the plot of the song, since it turns out that you need not sleep because of the "game", while the general concept leads to another action, to the refusal of sleep in spite of the "game". In this penultimate song of the cycle, the picture of the disharmony of life is finally emerging, in which "the eternal contradiction is the Kharms' miracle worker who did not perform a single miracle" (Tsoy \& Zhitinskij, 1991b, p. 127).

\section{Analysis of the third version}

The third draft of the song "Game": (refrain, numbering of the author of the article)

1. But now the trees are banging their branches against the windowpane.

2. You can lie down, fall asleep and kill this night.

3. The trees are banging their branches against the dark windowpane.

4. [as cats scratch]

5. How easy it is to fall asleep and kill this night. (Kalgin, 2016, p. 170)

(second verse, numbering of the author of the article)

1. To repeat doing what you did yesterday.

2. To talk about what you heard yesterday.

3. Tomorrow the sun will rise at 8 in the morning.

4. You can drink and be bored, you can just be bored.

5 . You can die of melancholy hearing the words "it's time".

6 . Tomorrow the sun will rise at 8 in the morning.

7. Tomorrow morning there will be no questions or secrets.

8. Tomorrow morning everything will be as it should. (Kalgin, 2016, p. 170).

In the third draft of the refrain, the image of a "cat" appears, but the author removes it; in the final version, the refrain sounds as follows:

But now the trees are banging their branches against the windowpane,

You can lie down, fall asleep and kill this night.

Trees like animals scratch the dark windowpane,

It is still not too late to lie down 
and fall asleep this night. (Tsoy \& Zhitinskij, 1991a, p. 321).

The image of animals is more consistent with the concept of the song, as it enhances the general tragedy of the lyrical plot, and also emphasizes the objectivity of the hero's worldview. The variant "cat" in this case excessively specifies the circumstances and their understanding. On the other hand, the poet, through such a change, creates a cycle-forming connection with the previous song, in which there are lines: "A beast sleeps in each of us" (Tsoy \& Zhitinskij, 1991a, p. 321).

Final version of the second verse:

No doorbells, no steps, no jingle of door keys,

The clock by the bed is barely audible, Everyone has been sleeping in this house for a long time.

Only drop by drop water flows out of the tap,

Only drop by drop days flow out of time,

You will go to cut wood, and you will see only stumps. (Tsoy \& Zhitinskij, 1991a, p. 321).

\section{The system of subject-object}

\section{relations}

In fact, the text of the second verse has been changed almost completely. Lines $1,2,4,5,7,8$ were removed from the third draft. The author metaphorically presented time in the form of a plumbing system, from which life flows out, drop by drop, second by second. Such a figurative comparison actualizes the meaninglessness and uselessness of being, since dripping from a tap is usually an indicator of something broken inside pipes and mechanisms, in fact, it is a waste of water. The connection of the category of time with the image of water, as well as light, has already been presented in the album previously associatively in the metaphor "electric rain" of the night in the song "Night". And the image of rain itself appeared in the fourth song of the cycle - "Dance". The appearance of the image of water as a sign of the time unites the songs of the cycle and leads to the general conceptual idea of the absurdity and uselessness of life. The theme of general disharmony is also developed in other compositions included in the cycle - "Mom Anarchy", "The stars will stay here", "The Last Hero" (Tsoy \& Zhitinskij, 1991b). In the second verse, the clock above the bed also appears as a sign of time, which also appeared only in the final version. The image of the bed includes in its semantics the state of morbidity. The author forms a general negative picture of the world, in which life is closed in a meaningless circle of repetitions, and time is a broken mechanism. A person is perceived as a kind of playing figure, which must act according to certain rules. The world around us levels out the personality of the subject. V. Kalgin (2016) cites the following lines, which became the beginning, the outline of the song "Game" (numbers near the lines were put by V. Kalgin):

1. It's late everyone's asleep and it's time for me to sleep.

6. Tomorrow morning I will wish I slept.

3. Tomorrow the sun will rise at 8 in the morning.

4. Strong morning tea, strong morning ice

5. Two of the rules of the game, and if 
you break them, you are gone.

2. The game starts tomorrow at eight in the morning.

No doorbells, no steps, no jingle of door keys.

The clock is barely audible as the metronome. (p. 170-171).

So, in the final version of the song "Game" Viktor Tsoy refuses the subjective transfer of the state in favor of the object. In particular, the personal pronoun of the first person singular "I" is replaced by the personal pronoun of the second person singular - "you", while: "The pronouns of the first and second person are included in the core of the language means of dialogization. They provide conditional personification of the presentation of complex information". (Tsin, 2017, p. 87). At the same time the personal pronoun "I" corresponds "each time to a single individual, taken precisely in his uniqueness". (Benvenist, 2002, p. 286).

\section{Discussion}

Thus, the author strengthens the element of trust in subject-object relations. Allowing the presence of a lyrical character in the artistic structure of the text, he objectifies the transmitted emotional states and the cognitive side of life. With the introduction of the personal pronoun of the second person, the process of dialogization develops, which helps to create comfortable communication in the perception of the text. The personal pronoun of the second person singular "you" has in its semantics the assumption of the presence of an outside person or persons to whom the appeal is formulated. In literary texts, according to scientists, this form of the part of speech performs an appellative function, which consists in the fact that the author addresses the reader or listener and also encourages him to the appropriate perception of speech (Murasheva, 2004).

During playback, the projection of all listened or read onto the world of the listener or reader occurs. It is easier for the poet to establish contact with the addressee of the text.

"Deicticity of semantics, which characterizes this pronoun in speech situations in real life, in poetry determines the unlimited choice of the addressee of the utterance. This is an abstract interlocutor, and a specific person or persons, and an inanimate object, and an abstract concept. In poetic works, the pronoun of the second person singular is characterized by several ways of semantization" (Murasheva, 2004, p. 16).

Among the types identified by researchers for this case, we can consider the two most consistent with the concept of the text.

First, it is "you, identical to me". In a context when the subject and the interlocutor are not distinguished, semantics is formed, in accordance with which the poet simultaneously addresses both the reader and himself (Murasheva, 2004). In the song of V.R. Tsoy, taking into account the information from the draft, one can also consider the change of subject to object as a sign of one of the ways the lyrical hero represents himself. We can talk about this semantic closeness of the author and the hero. 
Secondly, it is the "functional you". With the help of this meaning, the poet characterizes certain individuals in his poetic works. An important component of this situation is a certain meditative state of the heroes who are thinking about the eternal questions of being, about the meaning of their own life, about duty and responsibility, good and evil, about love and death (Murasheva, 2004). The song written by V.R. Tsoy also raises the question of the meaning of existence, the need for certain actions, and the choice. The final version of the song "Game" is shown in Figure 1.

In the light of all of the above, let's pay attention to the key concept of the song, namely, to what the author ultimately means by the word "game". In a postindustrial society, a man's personality is leveled by the rules of everyday life, behind which there are meaningless and monotonous actions. The hero cannot behave naturally during the day and is obliged to obey the general system, which does not allow him show his individuality. The game becomes the leading ontological property and representation of this world. A person in this world should behave like everyone else, not stand out ("Everyone has been sleeping in this house for a long time" (Tsoy \& Zhitinskij, 1991a, p. 321)). If you break the rules, then you are "gone". Everything natural must also obey certain rules, even the sun rises by alarm clock: "Tomorrow the sun will rise at 8 in the morning" (Tsoy \& Zhitinskij, 1991a, p. 321). And only night makes it possible to get away from the rules, to become what you are. The image of trees that "scratch the dark windowpane", giving out other sounds that turn out to be chaotic in comparison with the rhythmic clatter of clock and falling drops, represents something that is knocked out of this mechanistic system. They seem to call the hero out of this metal and glass world and free himself from it in his true natural state, to find the meaning of life in his nature, and not in artificial being. They call the hero to go outside the game. In this case, one of the important artistic principles of rock poetry is manifested. This is a mandatory protest against the routine, against the conformism of this world (Poliakov, 2017; Pond, 1987; Steinholt, 2005). The poet in this song focuses on the meaninglessness of life, into which the world drives the hero, and suggests finding a way out in the natural beginning. It is necessary to get rid of everyday life, break the rules and find the true meaning of being.

The above-mentioned changes in the representation of subject-object relations in draft versions of a rock composition emphasize the conceptual idea of the work. The author identifies himself with the hero, and at the same time, together with him, reflects on the eternal values of life. And it is quite naturally that in the final song of the rock album, which follows the considered composition "Game", there appears a unifying first-person plural pronoun "we".

Comparing the results of this research with similar Russian or foreign ones, it should be noted that the aspect of aesthetic information in song poetry is considered within the framework of interdisciplinary research. For example:

«it is noted that musical discourse reflects a complex relationships context which implies a special 
algorithm for understanding it as an artistic practice that exists in the context of a particular society and includes not only the contextual dimension of its existence, but also the goal, attitudes, and experience of the individual as the creator and the listener (Piatnitska-Pozdnyakova, 2020, p. 397).

At the same time, there is a growing awareness of aspects related to psychoanalysis and A.C. Sutton (Sutton, 2021) wrote about the (individual) subject observing the aesthetic object In our work, the emphasis is on the semantic content of subject-object relations and their implementation in the rock poet's work.

\section{Conclusion}

The above-mentioned changes in the representation of subject-object relations in draft versions of a rock composition emphasize the conceptual idea of the work. The author identifies himself with the hero, and at the same time, together with him, reflects on the eternal values of life. And quite naturally in the final song of the rock album, which follows the considered composition "Game", there appears a unifying first-person plural pronoun "we". In light of all of the above, let's pay attention to the key concept of the song, which is what the author ultimately means by the word - game. In a postindustrial society, a person's personality is leveled by the rules of everyday life, behind which there are meaningless and monotonous actions. The hero cannot behave naturally during the day and is obliged to obey the general system, which does not allow him to realize his individuality. The game becomes the leading ontological property and representation of this world. A person in this world should behave like everyone else, not stand out.

The image of trees that "scratch the dark windows", giving out other sounds that turn out to be chaotic in comparison with the rhythmic beat of clocks and falling drops, represents something that is knocked out of this mechanistic system. They seem to call the hero out of this metal and glass world and free himself from it in his true natural state, to find the meaning of life in his nature, and not in artificial being. Go outside the game. In this case, one of the important artistic principles of rock poetry is manifested this is a mandatory protest against the routine, against the conformism of this world.

\section{Limitations of Study}

The study of rock poetry in general and this study in particular makes it possible to focus on formulated ideas and use analytical tools in a similar way for other songs. The main constraints are generally taught by the amount of work and the need to bring in drafts. But the drafts have survived in small quantities, which in general causes difficulties. 


\section{Biodata of Author}

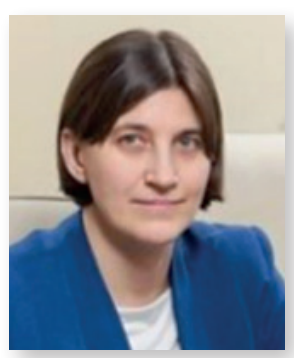

\section{Svetlana Andreevna Petrova}

Svetlana Andreevna Petrova, Candidate of Sciences in Philology - PhD (c), Associate Professor Interest of author: theory of intermediality, Russian rock poetry, song poetry, rock music, philology, composition, literary history. Affiliation: Pushkin Leningrad State University, Saint Petersburg, Russia e-Mmail: siversl@yandex.ru ORCID: https://orcid.org/0000-0002-2634-8473 Publons: https://publons.com/researcher/2076071/svetlana-apetrova/ https://www.scopus.com/authid/detail.uri?authorld=56584402900 Elibrary: https: / /www.elibrary.ru/author_profile.asp?id=675887 


\section{References}

Agawu K. (2009) Music as discourse: Semiotic adventures in romantic music. Oxford; New York: Oxford University Press, $345 \mathrm{p}$.

Ashworth, A. P. (2021). Associations with the Visual Arts in the Music of Debussy (Doctoral dissertation, The Open University).

Benvenist, Je. (2002). Priroda mestoimenij [The nature of pronouns]. In: Yu.S. Stepanov (Ed.), Obschaja lingvistika [General linguistics] (pp. 285291). Moscow: Editorial URSS.

Domanskij, Ju.V. (2000). Tsiklizacija v russkom roke [Cyclization in Russian rock]. Russkaja rok-pojezija: tekst i kontekst, 3, 99-122.

Domanskij, Ju.V. (2010). Russkaja rokpojezija: tekst i kontekst. Moscow: "Intrada" izd-vo Kulagina, 232 p.

Edwards, D., \& Potter, J. (2017). Some uses of subject-side assessments. Discourse studies, 19(5), 497-514.

Fomenko, I.V. (1992). Liricheskij cikl: stanovlenie zhanra, pojetika [Lyric cycle: the formation of the genre, poetics]. Tver: Tver State University, 123 p.

Guilbault, J. (2017). Interpreting world music: a challenge in theory and practice 1 (pp. 215-228). Routledge.

Hoffmann L. Kommunikationsmittel Fachsprache: Eine Einführung. 3. Aufl. Berlin : Sammlung Akademie-Verlag Sprache. 44 p.
Levinge, A. (2015). The music of being: Music therapy, Winnicott and the school of object relations. Jessica Kingsley Publishers. 42-46

Kalgin, V.N. (2016). Viktor Tsoj. Zhizn' i "Kino" [Viktor Tsoi. Life and "Kino"]. Moscow: Izd-vo AST, 304 p.

Murasheva, O.P. (2004). Semantika i funktsii mestoimeniy $v$ poeticheskim tekste [Semantics and functions of pronons in poetic text]. Yaroslavskiy pedagogicheskiy vestnik. Nauchnometodicheskiy zhurnal, 1-2(38-39), 1319.

Piatnitska-Pozdnyakova, I. S. (2020). Textual Space of the Music Discourse: Theory, Practice. Publishing House “Baltija Publishing”. 382-398

Poliakov, N. (2017). Seeking for God: Russian rock music and religion. Romanian Journal of Journalism \& Communication - Revista Romana de Jurnalism si Comunicare, 12(2-3), 5-15

Pond, I. (1987). Soviet rock lyrics: Their content and poetics. Popular Music \& Society, 11(4), 75-91.

Prica, I. M. (2019). The Effects of American Experimental Music in the Domain of Contemporary Art and Theory. New Sound International Journal of Music, 54(II), 185-187.

Steinholt, Y.B. (2005). Rock in the reservation: songs from Leningrad Rock Club 1981-86. New-York: Mass Media Music Scholars' Press, 230 p.

Sutton, A. C. (2021). Toward New 
Aesthetic Horizons: The Case for a Pragmatist-Hermeneutic Approach to Art Music. The American Sociologist, 1-27.

Tsin, J. (2017). Mestoimenija pervogo i vtorogo lica kak sredstvo dialogizacii v lekcionnoj kommunikativnoj praktike [FIrst-person and second-person pronouns as a means of dialogization in lecture communicative practice]. Vestnik Permskogo universiteta. Rossijskaja i zarubezhnaja filologija, 9(1), 87-92.

Tsoy, M., Zhitinskij, A. (1991a). Viktor Tsoy. Igra [Victor Tsoi. Game] In: Viktor Tsoy: Stihi, dokumenty, vospominanija [Victor Tsoi: Poems, documents, memoirs]. St. Petersburg: Novyj Gelikon, $382 \mathrm{p}$.

Tsoy, M., Zhitinskij, A. (1991b). Viktor Tsoy: Stihi, dokumenty, vospominanija [Victor Tsoi: Poems, documents, memoirs]. St. Petersburg: Novyj Gelikon, $382 \mathrm{p}$.

Valiquet, P. (2020). Contemporary Music and Its Futures. 187-205.

Wilson, S. (2020). Strategies of Conquest and Defence: Encounters with the Object in Twentieth-Century Music. Journal of the Royal Musical Association, 145(2), 457-484. 
The concept of subject-object relations in draft versions of the song "Game" by V.R. Tsoy 